\title{
Characterization of 16 novel microsatellite loci for Ephippiger diurnus (Orthoptera: Tettigoniidae) using pyrosequencing technology and cross-species amplification
}

\author{
Yareli ESQUER-GaRRIGOS ${ }^{1,2}$, Michael D. GREeNFIELD ${ }^{3}$, VIRGINIE PARTY³ and RéJane STREIFF ${ }^{1,2}$ \\ ${ }^{1}$ INRA, UMR 1062 CBGP, Campus International de Baillarguet, 34988 Montferrier-sur-Lez, France; \\ e-mails: esquergarrigos@gmail.com, streiff@supagro.inra.fr \\ 2 INRA, UMR 1333 DGIMI, Université de Montpellier, Place Eugène Bataillon, 34095 Montpellier cedex 5, France \\ ${ }^{3}$ Institut de Recherche sur la Biologie de I'Insecte (IRBI), CNRS UMR 7261, Parc de Grandmont, Université François Rabelais \\ de Tours, 37200 Tours, France; e-mails: michael.greenfield@univ-tours.fr, virginie.party@univ-tours.fr
}

Key words. Orthoptera, Tettigoniidae, Ephippiger diurnus, calling song, microsatellite polymorphism, katydid, population genetics

\begin{abstract}
A novel panel of 16 microsatellite markers, obtained by pyrosequencing of enriched genomic libraries, is reported for the flightless European bushcricket Ephippiger diurnus (Dufour) (Orthoptera: Tettigoniidae). Five multiplex and one simplex PCR protocols were optimized, and the polymorphism at the 16 loci was assessed in two natural populations from southern France. The mean allele number and (expected mean heterozygosity) were 8.94 (0.71) and 6.57 (0.70), respectively, in each population. Several loci were at Hardy-Weinberg disequilibrium (HWD), possibly due to the incidence of null alleles. The occurrence of null alleles has been previously reported for this species, and it is a common feature of microsatellite loci in Orthoptera. Cross-amplification tests demonstrated the transferability of some of these loci to other ephippigerine species. The microsatellite loci reported here substantially increase the number of available loci for this species and will afford an accurate picture of $E$. diurnus phylogeography, the genetic structure of its populations, and an improved understanding of the evolution of male song and other sexually-selected traits in this highly variable species.
\end{abstract}

\section{INTRODUCTION}

The European bushcricket Ephippiger diurnus (Orthoptera: Tettigoniidae) has attracted considerable attention among behavioral and evolutionary biologists because of its diverse calling songs (Duijm, 1990; Ritchie, 1996), large spermatophore (Barbosa et al., 2016), and a strong population genetic structure (Spooner \& Ritchie, 2006). E. diurnus are flightless, do not migrate, and have specific habitat preferences, and previous studies showed that they are distributed in geographically isolated, genetically differentiated populations throughout their range in southern France and northeastern Spain (Party et al., 2015). These geographically separate populations generally exhibit distinctive male songs that are characterized by a specific number of syllables per call (Ritchie, 1991, 1996), and some attempts have been made to relate the song trait to phylogeography by evaluating mitochondrial DNA (COI) divergence (Party et al., 2015). The various populations can be crossed in the laboratory (Ritchie, 2000), but the full potential of such hybridization is unknown. To determine the phylogeography of E. diurnus with greater precision and to explore the evolution of song diversity, genetic markers that afford reliable, fine-level resolution of population differences are needed.

The development of a minimal number of valuable microsatellite loci for population genetics (i.e. polymorphic, easily scorable, free of null alleles and conforming to Hardy-Weinberg expectations) has proven challenging in E. diurnus. Indeed, a set of 16 loci had been reported for this species before our study (Hockham et al., 1999; Hamill et al., 2006). According to the authors themselves, these loci displayed strong heterozygote deficit, and the incidence of null alleles was considerable for some of them. In a preliminary trial we tested 13 of these available 16 loci on samples from highly divergent populations previously characterized for mitochondrial DNA COI variation (Party et al., 2015). Most loci failed to amplify and/or presented complex allelic patterns impeding their scoring. This situation significantly reduced the number of available markers to only five, which is a minimum value for population genetic analyses. We therefore applied highthroughput (pyrosequencing) technology to a partial genomic library enriched in microsatellite motifs in order to increase the number of loci and filter out those of low quality according to criteria detailed below.

\section{MATERIAL AND METHODS}

\section{Sample collection and DNA extraction}

Fifty-one specimens of E. diurnus were collected from nine localities in southern France between 2011 and 2014 (Fig. 1). Hind femora were dissected and preserved in $95 \%$ ethanol for DNA 


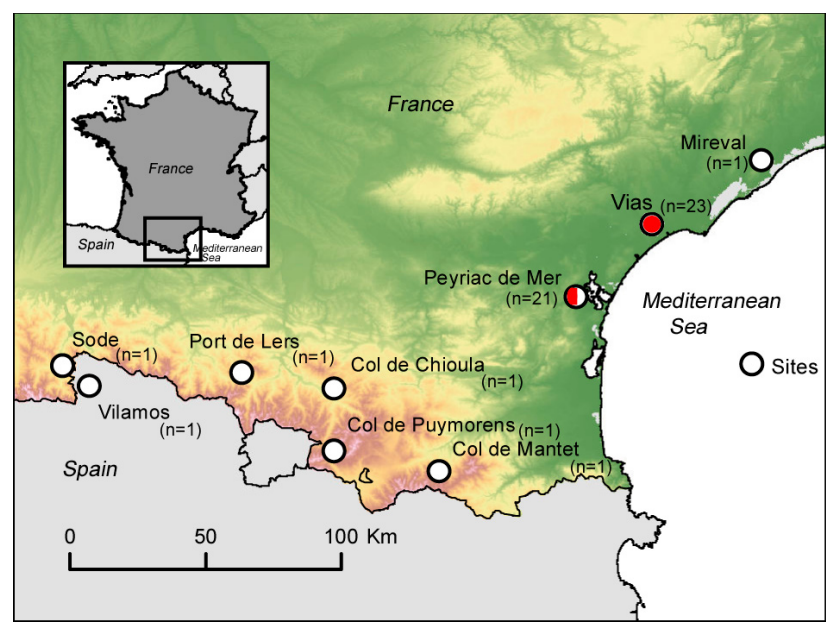

Fig. 1. Localities and number of sampled specimens (n) in south France. Circles represent sampled localities for microsatellite enriched DNA libraries construction, PCR amplification test (white) and/or polymorphism analysis (red).

extraction. Whole genomic DNA was extracted using the DNA Easy Blood and Tissue kit (Qiagen, Hilden, Germany) following the manufacturer's instructions. DNA quality and molecular weight were assessed in a $1 \%$ agarose gel and with a Nanodrop 2000 spectrophotometer (Thermo Scientific, Villebon sur Yvette, France).

\section{Microsatellite isolation}

Five $\mu \mathrm{g}$ of DNA were obtained by pooling individual DNA extracts from eight insects sampled in eight of nine localities (Fig 1). The DNA pool was sent to Genoscreen, Lille, France (www. genoscreen.fr) for microsatellite isolation through 454 GS-FLX Titanium pyrosequencing of enriched DNA libraries following the approach described by Malausa et al. (2011). Briefly, enriched libraries were constructed using eight microsatellite probes (TG, TC, AAC, AAG, AGG, ACG, ACAT, ACTC), and the resulting library was sequenced on a GsFLX PTP. The resulting 72,447 reads were analyzed using the program QDD (Meglecz et al., 2010) and sorted according to the following criteria: number of microsatellite repeats $\geq 5$, microsatellite motif not interrupted by any other bases or sequences, fragment size $\geq 80 \mathrm{bp}$. A fasta file with 5,027 reads containing a microsatellite repeat and a list of optimized primer pairs for 503 reads (size range: $90-319 \mathrm{bp}$ ) was provided by Genoscreen. Within these reads, 323 primer pairs with expected fragment sizes $\geq 120 \mathrm{bp}$ were chosen. Special attention was paid to homologous sequences shared among distinct reads: short, repeated sequences in the vicinity of microsatellites are frequently shared among distinct loci and impede consistent single locus PCR amplifications if primers overlap them (Meglécz et al., 2007). To avoid this problem, sequences homologous among different reads identified after an "all-against-all" BLASTn analysis (http://blast.ncbi.nlm.nih.gov/Blast.cgi) were masked before primer design. In the same line, all sequences were checked and masked for the presence of known annotated repeated elements in the flanking regions by the RepeatMasker software (http://www.repeatmasker.org/) and the related domestic silkworm database. Finally, 100 loci were chosen to proceed with the first PCR screening using unlabeled primers (Eurofins Genomics, Ebersberg, Germany). For some of these loci new primers were designed when the expected amplification size was not adequate for the posterior multiplexing PCR procedure and or when primers provided by Genoscreen were located in zones of high homology according to our BLASTn analysis (Table S1).
Because of the high level of divergence among mtDNA COI clades (see Fig. 4 in Party et al., 2015) we tested PCR amplification of the 100 loci in four specimens of E. diurnus collected in Mireval, Sode, Port de Lers, and Col de Mantet (Fig. 1), and belonging to the two main COI clades (Fig. 1 in Party et al., 2015). Sequences and primers for the 100 loci are given in Table S1. Thus, we could retain only those loci amplifying unambiguously in all clades (Table S1). All amplifications were achieved with an ABI GeneAmp PCR System 2700 thermal cycler. PCR reactions were carried out in a $10-\mu 1$ solution containing the following: $2 \mathrm{mM} \mathrm{MgCl}, 2 \mathrm{mM}$ DNTPs, $1 \times$ PCR Buffer, 0.5 unit of GoTaq G2 polymerase (Promega, Charbonnieres, France), $2 \mu \mathrm{M}$ of each forward and reverse primer and $\sim 10 \mathrm{ng}$ of template DNA. PCR cycling conditions were as follows: $95^{\circ} \mathrm{C} 3 \mathrm{~min}$, followed by 30 cycles at $94^{\circ} \mathrm{C} 30 \mathrm{~s}, 60 \mathrm{~s}$ at $60^{\circ} \mathrm{C}, 72^{\circ} \mathrm{C}$ for $45 \mathrm{~s}$, and a final extension step of $10 \mathrm{~min}$ at $72^{\circ} \mathrm{C}$. PCR products were resolved in a $2 \%$ agarose gel. Twenty-one primers not amplifying in all four specimens (i.e. partial PCR amplification) were not considered. Forty-two primer pairs that showed clear, reproducible and unique fragments in the four specimens were retained for further analysis. Among them, eight loci showed an incidence of smear or amplified nonspecific bands, thereby justifying a $+3^{\circ} \mathrm{C}$ increase of the annealing temperature (Table S1). Lastly, 37 loci did not amplify at $60^{\circ} \mathrm{C}$ and were tested at $52^{\circ} \mathrm{C}$ using the same PCR conditions as above but were not tested in the following steps described below (Table S1).

Fragment analysis of 42 loci followed the cost-effective M13 fluorescent protocol described by Schuelke (2000) with modifications described below. Each forward primer was tagged at its 5' end with one 18-19 bp tail described in Culley et al. (2013) and one fluorescent label depending on the expected amplification size to allow posterior PCR multiplexing (Table S1). The combination of tails and fluorescent labels were as follows: M13 modA-NED, M13 modB-PET, T7 term-VIC and M13 (-21)-FAM (Applied Biosystems, Warrington, UK, see Table 1). Simplex PCR tests were performed on four to eight specimens to confirm PCR amplification with tailed primers. The $6.25 \mu$ l PCR reaction contained: $3.25 \mu$ l Multiplex PCR Master mix (Qiagen), 1 $\mu 1$ of a primer mix per locus containing: $2 \mu \mathrm{M}$ of each reverse and labeled tail primer and $0.5 \mu \mathrm{M}$ of the forward tailed primer (ratio: $1: 1: 1 / 4$, see Culley et al., 2013), $1 \mu \mathrm{L} \mathrm{H}_{2} \mathrm{O}$ and $1 \mu \mathrm{l}$ of DNA $(\sim 10 \mathrm{ng} / \mu \mathrm{l})$. PCR cycling conditions followed a denaturing step of $15 \mathrm{~min}$ at $95^{\circ} \mathrm{C}$, then 30 cycles at $94^{\circ} \mathrm{C}$ for $30 \mathrm{~s}, 60^{\circ} \mathrm{C}$ or $63^{\circ} \mathrm{C}$ (Table S1) for $45 \mathrm{~s}$ and $72^{\circ} \mathrm{C}$ for $45 \mathrm{~s}$; and then 8 cycles of $94^{\circ} \mathrm{C}$ for $30 \mathrm{~s}, 53^{\circ} \mathrm{C}$ for $45 \mathrm{~s}$ and $72^{\circ} \mathrm{C}$ for $45 \mathrm{~s}$ and a final elongation step of $10 \mathrm{~min}$ at $72^{\circ} \mathrm{C}$. PCR products were visualized on a $2 \%$ agarose gel. Fragment analysis was conducted on a 3730 xl DNA Analyzer (Applied Biosystems) using the GeneScan 500 LIZ as internal size standard (Applied Biosystems) and 1 to $2 \mu 1$ of PCR product (1:20 dilution). After visual screening of electropherogram profiles in GeneMapper version 5.0 (Applied Biosystems), 25 primers were selected for their scoring in additional specimens. Finally, 16 primer pairs showing polymorphism and unambiguous profiles were retained. For loci showing noisy electropherograms, the annealing temperature was increased by $3^{\circ} \mathrm{C}$ (Table S1).

\section{Multiplex PCR amplification}

We used Multiplex Manager version 1.0 (Holleley \& Geerts, 2009) to determine the best combination of loci in a multiplexed PCR amplification protocol. Five multiplex PCR amplification reactions and one simplex PCR were defined for the final set of 16 loci, and these were amplified in two populations of $E$. diurnus (Vias and Peyriac de Mer; Table 2) belonging to each of the two main mtDNA COI clades described in Party et al. (2015, see 
Table 1. Characteristics of 16 microsatellite loci from Ephippiger diurnus. Abbreviations: $F$ - the forward primer sequences; $R$ - the reverse primer sequences; $\mathrm{Ta}$ - annealing temperature.

\begin{tabular}{|c|c|c|c|c|c|c|c|c|}
\hline Locus & Repeat & Primer sequence $\left(5^{\prime}-3^{\prime}\right)$ & $\begin{array}{l}\text { Expected } \\
\text { size (bp) }\end{array}$ & Dye & Tail $^{\text {a }}$ & $\operatorname{Ta}\left({ }^{\circ} \mathrm{C}\right)$ & $\begin{array}{l}\mathrm{PCR} \\
\text { reaction }\end{array}$ & Primer mix $(\mu \mathrm{M})$ \\
\hline Ediur_3 & $(G A)_{9}$ & $\begin{array}{l}\text { F: TTG CAA TGA AAC GTT CTT CCT } \\
\text { R: TGA CCA GCA TTC TGT CTT GG }\end{array}$ & 216 & FAM & M13 (-21) & 60 & Multiplex 1 & $\begin{array}{l}\mathrm{F} \text { tailed }+ \text { tail }=0.7 \\
\mathrm{R}=2\end{array}$ \\
\hline Ediur_4 & $(\text { ATAC })_{12}$ & & 235 & VIC & T7 term & 63 & Simplex & $\begin{array}{l}\mathrm{F} \text { tailed }+ \text { tail }=0.7 \\
\mathrm{R}=2\end{array}$ \\
\hline Ediur_6 & $(\mathrm{TGT})_{6}$ & & 205 & VIC & T7 term & 60 & Multiplex 1 & $\begin{array}{l}\mathrm{F} \text { tailed }+ \text { tail }=0.7 \\
\mathrm{R}=2\end{array}$ \\
\hline Ediur_8 & $(\mathrm{TGTA})_{7}$ & & 175 & VIC & T7 term & 60 & Multiplex 2 & $\begin{array}{l}\mathrm{F} \text { tailed }+ \text { tail }=0.7 \\
\mathrm{R}=2\end{array}$ \\
\hline Ediur_20 & $(\mathrm{ACA})_{5}$ & & 236 & FAM & M13 (-21) & 60 & Multiplex 2 & $\begin{array}{l}\mathrm{F} \text { tailed }+ \text { tail }=0.7 \\
\mathrm{R}=2\end{array}$ \\
\hline Ediur_21 & $(\mathrm{TTG})_{9}$ & & 227 & PET & M13 modB & 60 & Multiplex 4 & $\begin{array}{l}\mathrm{F} \text { tailed }+ \text { tail }=1 \\
\mathrm{R}=2.3\end{array}$ \\
\hline Ediur_22 & $(A C)_{12}$ & $\begin{array}{l}\text { F: CCC CTC AAA TAT CCC AAC AC } \\
\text { R: CGC AAT GTC GAA CAC ATT TT }\end{array}$ & 189 & FAM & M13 (-21) & 63 & Multiplex 5 & $\begin{array}{l}\mathrm{F} \text { tailed }+ \text { tail }=0.7 \\
\mathrm{R}=2\end{array}$ \\
\hline Ediur_25 & $(\mathrm{AAG})_{7}$ & $\begin{array}{l}\text { F: AAA GCT ATT GGG TTT GTG GAA } \\
\text { R: CCA CCA ACT GAA CAG TGT CCT }\end{array}$ & 214 & PET & M13 modB & 60 & Multiplex 1 & $\begin{array}{l}\mathrm{F} \text { tailed }+ \text { tail }=1 \\
\mathrm{R}=2.3\end{array}$ \\
\hline Ediur_47 & $(\mathrm{TGA})_{10}$ & $\begin{array}{l}\text { F: TGG GAA ACA TGG AAA GGT GT } \\
\text { R: CCT GTC ATT TGC TGC TTC CT }\end{array}$ & 149 & VIC & T7 term & 63 & Multiplex 5 & $\begin{array}{l}\mathrm{F} \text { tailed }+ \text { tail }=0.7 \\
\mathrm{R}=2\end{array}$ \\
\hline Ediur_48 & $(\mathrm{AC})_{6}$ & $\begin{array}{l}\text { F: AAC CCA CCG GCC TAT TAA CT } \\
\text { R: GGC AAA CTC CAG TCA TCC AT }\end{array}$ & 227 & VIC & T7 term & 60 & Multiplex 4 & $\begin{array}{l}\mathrm{F} \text { tailed }+ \text { tail }=0.7 \\
\mathrm{R}=2\end{array}$ \\
\hline Ediur_55 & $(\text { ATAG })_{13}$ & & 135 & PET & M13 modB & 60 & Multiplex 2 & $\begin{array}{l}\mathrm{F} \text { tailed }+ \text { tail }=1 \\
\mathrm{R}=2.3\end{array}$ \\
\hline Ediur_57 & $(\mathrm{CA})_{7}$ & $\begin{array}{l}\text { F: TGA ACA AGA AAT AGA GGC GAG A } \\
\text { R: ATT TCT GTG GCG TGA TGT GA }\end{array}$ & 123 & VIC & T7 term & 60 & Multiplex 3 & $\begin{array}{l}\mathrm{F} \text { tailed }+ \text { tail }=0.7 \\
\mathrm{R}=2\end{array}$ \\
\hline Ediur_59 & $(\text { TGAT })_{6}$ & $\begin{array}{l}\text { F: TCT GGC CAT ATT AAG GGAAAT G } \\
\text { R: TGA CAT GGA GTG ATG GAT GG }\end{array}$ & 237 & PET & M13 modB & 60 & Multiplex 3 & $\begin{array}{l}\mathrm{F} \text { tailed }+ \text { tail }=1 \\
\mathrm{R}=2.3\end{array}$ \\
\hline Ediur_75 & $(\mathrm{AC})_{16}$ & $\begin{array}{l}\text { F: TTT GGT GCT AGC GTT GAG TG } \\
\text { R: CGT GCT TGA CAG ACC TCA GA }\end{array}$ & 160 & NED & M13 modA & 60 & Multiplex 4 & $\begin{array}{l}\mathrm{F} \text { tailed }+ \text { tail }=1 \\
\mathrm{R}=2.3\end{array}$ \\
\hline Ediur_85 & $(\text { ATG })_{8}$ & $\begin{array}{l}\text { F: TGT CGG TCT AAG GCC CAT AC } \\
\text { R: CAA TTG ACC TAA TGC AGG TGA C }\end{array}$ & 240 & FAM & M13 (-21) & 60 & Multiplex 4 & $\begin{array}{l}\mathrm{F} \text { tailed }+ \text { tail }=0.7 \\
\mathrm{R}=2\end{array}$ \\
\hline Ediur_86 & $(\mathrm{TTG})_{9}$ & $\begin{array}{l}\text { F: AAT GCA TCC AAC CGA CTA CC } \\
\text { R: TGC TAA CTT ATT CCG GTG GC }\end{array}$ & 297 & VIC & T7 term & 60 & Multiplex 2 & $\begin{array}{l}\mathrm{F} \text { tailed }+ \text { tail }=0.7 \\
\mathrm{R}=2\end{array}$ \\
\hline
\end{tabular}

a Tail primer sequences from Culley et al. (2013): M13 (-21) TGT AAA ACG ACG GCC AGT, M13 modA TAG GAG TGC AGC AAG CAT, M13 modB CAC TGC TTA GAG CGA TGC, T7 term CTA GTT ATT GCT CAG CGG T. Modified F and R primers are highlighted (see Table S1).

Table 2. Characteristics of 16 microsatellite loci from two populations of Ephippiger diurnus. Abbreviations: $\mathrm{N}$ - number of genotyped specimens; $\mathrm{Na}$ - number of alleles; $\mathrm{Ho}$ - observed heterozygosity; $\mathrm{He}$ - expected heterozygosity.

\begin{tabular}{|c|c|c|c|c|c|c|c|c|c|c|}
\hline \multirow[b]{2}{*}{ Locus } & \multicolumn{5}{|c|}{ Vias $(N=23)$} & \multicolumn{5}{|c|}{ Peyriac de Mer $(\mathrm{N}=21)$} \\
\hline & $\begin{array}{l}\text { Size range } \\
\text { (bp) }\end{array}$ & $\mathrm{Na}$ & Ho & $\mathrm{He}$ & $\begin{array}{l}\text { Null alleles } \\
\text { frequency }\end{array}$ & $\begin{array}{l}\text { Size range } \\
\text { (bp) }\end{array}$ & $\mathrm{Na}$ & Ho & $\mathrm{He}$ & $\begin{array}{l}\text { Null alleles } \\
\text { frequency }\end{array}$ \\
\hline Ediur_3 & $226-232$ & 4 & 0.04 & $0.59^{* *}$ & 0.34 & $228-238$ & 4 & 0.50 & 0.61 & \\
\hline Ediur_4 & $229-284$ & 14 & 0.50 & $0.91^{* *}$ & 0.21 & $225-280$ & 11 & 0.58 & $0.83^{* *}$ & 0.14 \\
\hline Ediur_6 & $220-247$ & 6 & 0.22 & $0.61^{* *}$ & 0.24 & $226-238$ & 4 & 0.76 & 0.69 & \\
\hline Ediur_8 & $143-261$ & 20 & 0.61 & $0.95^{\star *}$ & 0.17 & $161-241$ & 13 & 0.62 & $0.86^{* *}$ & 0.12 \\
\hline Ediur_20 & $247-271$ & 7 & 0.35 & $0.82^{* *}$ & 0.26 & $234-259$ & 8 & 0.25 & $0.82^{* *}$ & 0.31 \\
\hline Ediur_21 & $205-247$ & 8 & 0.65 & 0.82 & 0.09 & 219-244 & 5 & 0.45 & 0.45 & \\
\hline Ediur_22 & $186-207$ & 10 & 0.61 & 0.77 & 0.09 & 186-195 & 5 & 0.70 & $0.64^{* *}$ & \\
\hline Ediur_25 & $207-237$ & 6 & 0.68 & 0.71 & & $210-240$ & 6 & 0.81 & 0.79 & \\
\hline Ediur_47 & $160-190$ & 11 & 0.54 & $0.85^{\star *}$ & 0.16 & $160-200$ & 7 & 0.38 & 0.56 & 0.12 \\
\hline Ediur_48 & $236-245$ & 7 & 0.58 & 0.73 & & $235-243$ & 5 & 0.67 & 0.68 & \\
\hline Ediur_55 & $120-260$ & 18 & 0.65 & 0.85 & 0.11 & $121-204$ & 6 & 0.37 & $0.72^{* *}$ & 0.20 \\
\hline Ediur_57 & $137-142$ & 4 & 0.30 & 0.33 & & $137-145$ & 3 & 0.43 & 0.41 & \\
\hline Ediur_59 & 244-305 & 9 & 0.12 & $0.87^{\star *}$ & 0.40 & 244-305 & 7 & 0.41 & $0.79^{* *}$ & 0.21 \\
\hline Ediur_75 & $157-182$ & 9 & 0.27 & $0.78^{* *}$ & 0.28 & $150-174$ & 9 & 0.76 & 0.82 & \\
\hline Ediur_85 & $245-291$ & 9 & 0.91 & 0.82 & & $242-272$ & 7 & 0.86 & 0.80 & \\
\hline Ediur_86 & 301 & 1 & 0 & 0 & & 301-339 & 5 & 0.30 & $0.76^{\star *}$ & 0.26 \\
\hline Mean & & 8.94 & 0.44 & 0.71 & & & 6.57 & 0.55 & 0.70 & \\
\hline$\overline{\mathrm{SE}}$ & & 1.25 & 0.06 & 0.06 & & & 0.67 & 0.05 & 0.03 & \\
\hline
\end{tabular}

** Significant deviations from Hardy-Weinberg equilibrium after Bonferroni correction $(P=0.003)$. 
Table 3. Cross-amplification of 16 microsatellite loci isolated for $E$. diurnus. The INRA collection ID code for each voucher specimen is given within parentheses. Abbreviations: Lat - Latitude; Long - Longitude.

\begin{tabular}{|c|c|c|c|c|c|c|c|c|c|}
\hline \multirow{2}{*}{ Taxon (INRA collection ID code) } & \multirow{2}{*}{$\begin{array}{l}\text { Sampling locality } \\
\text { Lat / Long }\end{array}$} & \multicolumn{8}{|c|}{ Locus } \\
\hline & & Ediur_3 & Ediur_4 & Ediur_6 & Ediur_8 & Ediur_20 & Ediur_21 & Ediur_22 & Ediur_25 \\
\hline E. provencialis (JSTR02143_0101) & $43.6389 / 5.9356$ & + & - & - & - & - & + & - & + \\
\hline E. provencialis (JSTR02144_0101) & $43.6389 / 5.9356$ & + & - & - & - & - & + & - & + \\
\hline E. terrestris (JSTR02148_0101) & $43.7241 / 6.6297$ & + & - & - & + & - & - & - & + \\
\hline E. terrestris (JSTR02149_0101) & $43.7241 / 6.6297$ & + & - & - & + & - & - & - & + \\
\hline U. rugosicollis (JSTR02145_0101) & $44.0419 / 4.8971$ & - & - & + & - & + & + & - & + \\
\hline \multirow[t]{2}{*}{ U. rugosicollis (JSTR02146_0101) } & $44.0419 / 4.8971$ & - & - & + & - & + & + & - & + \\
\hline & & Ediur_47 & Ediur_48 & Ediur_55 & Ediur_57 & Ediur_59 & Ediur_75 & Ediur_85 & Ediur_86 \\
\hline E. provencialis (JSTR02143_0101) & & - & + & - & + & - & + & + & - \\
\hline E. provencialis (JSTR02144_0101) & & - & + & - & + & - & + & + & - \\
\hline E. terrestris (JSTR02148_0101) & & - & + & - & + & - & + & + & - \\
\hline E. terrestris (JSTR02149_0101) & & - & + & - & + & - & + & + & - \\
\hline U. rugosicollis (JSTR02145_0101) & & - & + & - & + & - & + & + & + \\
\hline U. rugosicollis (JSTR02146_0101) & & - & + & - & + & - & + & + & + \\
\hline
\end{tabular}

Figs 1 and 4). The multiplexed PCR reactions were carried out in a final volume of $6.25 \mu 1$ using $3.25 \mu 1$ Multiplex PCR Master mix (Qiagen), $1 \mu \mathrm{l}$ of multiplex primer mix (see Table 1), $1 \mu \mathrm{l}$ of DNA $(\sim 10 \mathrm{ng} / \mu \mathrm{l})$ and $1 \mu \mathrm{l} \mathrm{H}_{2} \mathrm{O}$. PCR cycling conditions for the five multiplex reactions were: $15 \mathrm{~min}$ at $95^{\circ} \mathrm{C}$, then 30 cycles at $94^{\circ} \mathrm{C}$ for $45 \mathrm{~s}, 60^{\circ} \mathrm{C}$ or $63^{\circ} \mathrm{C}$ for $90 \mathrm{~s}$ and $72^{\circ} \mathrm{C}$ for $60 \mathrm{~s}$; and then 8 cycles of $94^{\circ} \mathrm{C}$ for $30 \mathrm{~s}, 53^{\circ} \mathrm{C}$ for $45 \mathrm{~s}$ and $72^{\circ} \mathrm{C}$ for $45 \mathrm{~s}$ and a final elongation step of $30 \mathrm{~min}$ at $60^{\circ} \mathrm{C}$. PCR cycling conditions for the simplex PCR followed the same simplex PCR protocol described above.

\section{Polymorphism analysis}

The allele number, heterozygosity and Hardy-Weinberg equilibrium (HWE) for each loci were computed in GENEPOP version 4.3 (Rousset, 2008). $P$ values were adjusted for multiple tests of significance using the sequential Bonferroni correction at the $5 \%$ nominal level (Rice, 1989). Incidence of null alleles was assessed on Micro-checker version 2.2.3 (Van Oosterhout et al., 2004), and when significant their frequency was obtained using the Brookfield 1 method. GenBank numbers (KU512644-KU512669) were attributed only to primary sequences (Table S1).

\section{Cross-amplification}

The final set of 16 loci was cross-amplified in two other species of Ephippiger and in one species of Uromenus using the simplex PCR amplification protocol described above (Table 3).

\section{RESULTS AND DISCUSION}

Microsatellite loci isolated from E. diurnus showed moderate to high levels of allelic diversity and were polymorphic in both populations analyzed, except for locus Ediur86 in Vias. The number of alleles ranged from four to 20 in Vias $(N=23)$, with a mean of 8.94 alleles per locus, and from three to 13 in Peyriac de Mer $(\mathrm{N}=21)$, with a mean of 6.57 alleles per locus. The expected heterozygosity ranged from 0 to 0.95 in Vias, with a mean of 0.71 , and from 0.41 to 0.86 in Peyriac de Mer, with a mean of 0.70 . Heterozygote deficiency and significant departure from HWE were detected for several loci in both populations after Bonferroni correction (Table 2). The analysis of the distribution of homozygote size classes on Micro-checker suggested the incidence of null alleles that might contribute to the observed heterozygote deficiency and HWD in both populations (Table 2). No scoring errors due to stuttering or large allele drop-out were detected. The frequency of null alleles ranged from 0.09 to 0.40 in Vias and from 0.12 to 0.31 in Peyriac de Mer. A high proportion and preva- lence of null alleles at microsatellite loci are common in Orthoptera (Zhang et al., 2003; Chapuis et al., 2005; Chapuis \& Estoup, 2007), and Ephippiger diurnus seems not to be an exception. Previous reports on microsatellite characterization for this species also showed a considerable prevalence of null alleles (Hockham et al., 1999; Hamill et al., 2006). The distribution of E. diurnus in small, genetically differentiated populations, an outcome of low dispersal and specific habitat preferences, probably contributes to the observed heterozygote deficiency.

The microsatellite markers we report for E. diurnus will be valuable for fine level phylogeographic analysis and studies at larger geographical scale, and for studying the diversity of the male calling song and female preferences. Cross-amplification tests showed the transferability of this set of microsatellite markers to other Ephippiger species as well as to another ephippigerine, Uromenus rugosicollis (Table 3 ).

ACKNOWLEDGEMENTS. We thank J.-C. Streito and A. Foucart for collecting specimens for the cross-amplification tests. F. Cerqueira, E. Desmarais and T. Cantinelli (Centre Méditerranéen Environnement Biodiversité; Labex CEMEB) provided technical support with genotyping. The DGIMI (Diversité, génome \& interactions microorganisms-insectes, UMR INRA 1333 - Université de Montpellier) research unit made its laboratory facilities available for our analyses. This study was funded by grant ANR11-BSV7-025-01 (EVOLCHOR) from the Agence Nationale de la Recherche de France.

\section{REFERENCES}

Barbosa F., Rebar D. \& Greenfield M.D. 2016: Reproduction and immunity tradeoffs constrain mating signals and nuptialgift size in a bushcricket. — Behav. Ecol. 27: 109-117.

Chapuis M.P. \& Estoup A. 2007: Microsatellite null alleles and estimation of population differentiation. - Mol. Biol. Evol. 24: 621-631.

Chapuis M.P., Loiseau A., Michalakis Y. \& Estoup A. 2005: Characterization and PCR multiplexing of polymorphic microsatellite loci for the locust Locusta migratoria. - Mol. Ecol. Notes 5: 554-557.

Culley T.M., Stamper T.I., Stokes R.L., Brzyski J.R., Hardiman N.A., Klooster M.R. \& MerRitt B.J. 2013: An efficient technique for primer development and application that integrates fluorescent labeling and multiplex PCR. - Appl. Plant Sci. 1: 1300027, 10 pp. 
Duisм M. 1990: On some song characteristics in Ephippiger (Orthoptera, Tettigonioidea) and their geographic variation. Netherl. J. Zool. 40: 428-453.

Hamill R.M., Noor M.A.F., Watson E.T. \& Ritchie M.G. 2006: New microsatellite loci for the European bushcricket, Ephippiger ephippiger (Orthoptera: Tettigoniidae). - Mol. Ecol. Notes 6: 340-342.

Hockham L.R., Graves J.A. \& Ritchie M.G. 1999: Isolation and characterization of microsatellite loci in the bushcricket Ephippiger ephippiger (Orthoptera: Tettigoniidae). - Mol. Ecol. 8: 905-906.

Holleley C.E \& GeERTs P.G. 2009: Multiplex Manager 1.0: a crossplatform computer program that plans and optimizes multiplex PCR. - BioTechniques 46: 511-517.

Malausa T., Gilles A., Meglécz E., Blanquart H., Duthoy S., Costedoat C., Dubut V., Pech N., Castagnone-Sereno P., DÉLYE C. ET AL. 2011: High-throughput microsatellite isolation through 454 GS-FLX Titanium pyrosequencing of enriched DNA libraries. - Mol. Ecol. Resour. 11: 638-644.

Meglécz E., Anderson S.J., Bourquet D., Butcher R., Caldas A., Cassel-Lundhagen A., D'Acier A.C., Dawson D.A., Faure N., Fauvelot C. et AL. 2007: Microsatellite flanking region similarities among different loci within insect species. - Insect Mol. Biol. 16: 175-185.

Meglécz E., Costedoat C., Dubut V., Gilles A., Malausa T., PeCh N. \& MARTin J.F. 2010: QDD: a user-friendly program to select microsatellite markers and design primers from large sequencing projects. - Bioinformatics 26: 403-404.

Party V., Streiff R., Marin-Cudraz T. \& Greenfield M.D. 2015 Group synchrony and alternation as an emergent property: elaborate chorus structure in a bushcricket is an incidental byproduct of female preference for leading calls. - Behav. Ecol. Sociobiol. 69: 1957-1973.
Rice W.R. 1989: Analyzing tables of statistical tests. — Evolution 43: 223-225.

RitchiE M.G. 1991: Female preference for "song races" of Ephippiger ephippiger (Orthoptera: Tettigoniidae). - Anim. Behav. 42: $518-520$.

Ritchie M.G. 1996: The shape of female mating preferences. Proc. Natl. Acad. Sci. USA 93: 14628-14631.

Ritchie M.G. 2000: The inheritance of female preference functions in a mate recognition system. - Proc. R. Soc. Lond. (B) 267: 327-332.

RousseT F. 2008: GENEPOP'007: A complete re-implementation of the GENEPOP software for Windows and Linux. - Mol. Ecol. Resour. 8: 103-106.

SCHUELKE M. 2000: An economic method for the fluorescent labeling of PCR fragments. - Nat. Biotechnol. 18: 233-234.

Spooner L.J. \& Ritchie M.G. 2006: An unusual phylogeography in the bushcricket Ephippiger ephippiger from southern France. - Heredity 97: 398-408.

Van Oosterhout C., Hutchinson W.F., Willis D. \& Shipley P. 2004: Micro-checker: Software for identifying and correcting genotyping errors in microsatellite data. - Mol. Ecol. Notes 4: 535-538.

Zhang D.X., Yan L.N., Ji Y.J., Le Kang, Hewitt G.M. \& Huang Z.S. 2003: Isolation, characterization and cross-species amplification of eight microsatellite DNA loci in the migratory locust (Locusta migratoria). — Mol. Ecol. Notes 3: 483-486.

Received January 22, 2016; revised and accepted March 4, 2016 Published online April 5, 2016

Supplementary file:

Table S1 (http://www.eje.cz/2016/037/S01.xls). 